\title{
A SOCIEDADE ENQUANTO DUELO DE IMITAÇÕES. Uma releitura de Tarde, G. (1978 [1890]). As leis da imitação. Porto: Rés Editora
}

\author{
Pedro Rodrigues Costa' ${ }^{1}$ (D)
}

Revisitar o livro As Leis da Imitação, um original de Gabriel Tarde de 1890, pode parecer tardio e fora de tempo se concluirmos que já conta com 131 anos de existência. Porém, numa contingência fortemente marcada por relações, conversações e interações mediadas por computadores e conectadas por internet, em plataformas digitais habitualmente animadas por possibilidades de partilha, comentário e cópia de conteúdo, acreditamos que revisitar este clássico, que se debruça precisamente sobre semelhanças e cópias, permitirá algumas (in)flexões à teoria social, renovando-a. Além disso, acresce a esta revisitação uma outra contingência: a pandemia de Covid-19. O atual momento histórico recorda-nos, precisamente, uma ideia latente e invariavelmente esquecida ao longo do tempo, todavia plasmada em várias obras deste sociólogo francês, que aqui, em particular, alcança maior amplitude: tal como os vírus vivem nos hospedeiros, também as semelhanças habitam em quem imita socialmente. Estas duas razões bastam-nos para demonstrar o conjunto de potencialidades teóricas inscritas na revisitação deste clássico.

Esta versão de As Leis da Imitação, traduzida pela Rés Editora, começa com dois prefácios do autor um referente à primeira edição e outro referente à segunda. A intenção de Tarde com estes prefácios era a de clarificar algumas leituras posteriores à primeira edição. No prefácio à segunda edição, faz notar que por imitação entende toda a ação à distân- cia "de um espírito sobre um outro, e de uma ação que consiste numa reprodução quase fotográfica de um cliché cerebral pela placa sensível de um outro cérebro ou do mesmo cérebro, se se tratar da imitação de si mesmo" (Tarde, 1978, p, 6). Tarde clarifica assim a imitação como "toda a gravação fotográfica inter-espiritual, por assim dizer, quer seja querida ou não, passiva ou activa" (Tarde, 1978, p. 6).

A partir daqui o autor reforça uma ideia que ao longo de várias páginas explora: que existem três formas principais de repetição universal - vibração, hereditariedade e imitação. Todavia, e como mensagem para os críticos à primeira edição, considera que só a imitação é social. Quer dizer, que "o carácter distintivo de qualquer relação social, de qualquer facto social, é ser imitativo" (Tarde, 1978, p. 8). No meio da "complexidade infinita" que caracteriza a trama de relações sociais, sublinha a existência de dois grandes objetos de transmissão: as crenças e os desejos, onde "uns são variedades ou veleidades de ensinamento, outros são variedades ou veleidades de comando" (Tarde, 1978, p. 8). Ideia esta que, ainda sem sairmos do prefácio, já nos conduz a várias obras posteriores, entre essas $O$ Anti-Édipo - Capitalismo e Esquizofrenia, de Deleuze \& Guattari (2004) e Diferença e Repetição, de Gilles Deleuze (2000).

Em seu entender, essa complexidade infinita existente nas relações sociais reside, precisamente, nos

${ }^{1}$ CECS-Communication and Society Research Center/University of Minho, Braga, Portugal/FCT-Fundação para a Ciência e a Tecnologia.

Este trabalho é apoiado por fundos nacionais através da FCT- Fundação para a Ciência e a Tecnologia. I.P., no âmbito do Financiamento Plurianual do Centro de Estudos de Comunicação e Sociedade 2020-2023 (que integra as parcerias de financiamento base, com a referência UIDB/00736/2020, e financiamento programático, com a referência UIDP/00736/2020). 
laços sociais estabelecidos pela imitação, o que o leva a considerar que a imitação "é um laço social; porque o que liga os homens é o dogma (ideia, religiosa ou não, política, por exemplo, ou outra qualquer, que se implanta no espírito de cada associado por pressão do ambiente) ou o poder" (Tarde, 1978, p.8).

Mas há uma nuance que Tarde pretende sublinhar ainda no prefácio: que "há duas maneiras de imitar: fazer exatamente como o seu modelo, ou fazer exatamente o contrário" (Tarde, 1978, p. 9). Ideia que difere, para o autor, da imitação em Spencer, na "lei da diferenciação progressiva” (Tarde, 1978, p. 10). Para concretizar esta diferença, Tarde sugere alguns exemplos: o sobrenatural afirma-se na teologia. Pelo contrário, o naturalismo como a sua negação. Já o espiritualismo sugere a ideia contrária, o materialismo, e a monarquia sugere a república (Tarde, 1978, p. 9). Esta simetria social germinou, mais recentemente, numa antropologia simétrica consagrada por Bruno Latour (2009).

Gabriel Tarde funda assim uma epistemologia a partir da ideia de que "uma sociedade é um grupo de pessoas que apresentam entre elas semelhanças produzidas por imitação ou por contra-imitação" (Tarde, 1978 , p. 9). Parte do pressuposto de que "os homens contra-imitam-se muito, sobretudo quando eles não têm nem a modéstia de imitar pura e simplesmente, nem a força de inventar" (Tarde, 1978, p. 9). E daqui nasce, em seu entender, um primeiro paradoxo da imitação: ao contra-imitar, ao fazer tudo de modo oposto, "vão assimilando cada vez mais" a corrente de imitação. Ao contra-imitar, o sujeito está a acionar a corrente de imitações. Ideia também presente na lei das correntes de indução ou mesmo na terceira lei de newton, em que a toda a ação corresponde uma reação oposta e de igual intensidade.

Todavia, há em Tarde uma complexidade humanista: o processo de contra-imitar não é uma invenção, pois "as próprias contra-correntes nascem da corrente" (Tarde, 1978, p. 10). Portanto, em Tarde contra-imitar não é imitar nem não-imitar. A "não-imitação não é um simples facto negativo". A não-imitação voluntária e perseverante "tem um sentido purificador, bastante análogo ao que desempenha o que eu chamei de duelo lógico" (Tarde, 1978, p. 11).
Um duelo lógico é, para o sociólogo, um facto social na medida em que todo "o facto social é uma relação de imitação". Logo, "o laço social, o grupo social, é, por sua vez, imitativo e hereditário" (Tarde, 1978, p. 13). O facto social surge como processo e nunca como acontecimento. Uma crise económica é um acontecimento derivado de um facto social, que é a imitação ou conjuntos de imitações que, ao obterem força em onda coletiva, a geram. Trata-se, portanto, de algo que atravessa o tempo e o espaço social e que se move entre mentes que estabelecem contacto de alguma forma. Um exemplo atual seria uma invenção extraída de uma dinâmica imitativa a partir de um meme circulante numa qualquer plataforma digital, gerando um posterior meme de valor partilhável. No sentido de Tarde, a invenção nasce "do reencontro do génio individual, erupção intermitente e característica da razão, fruto saboroso de uma série de casamentos felizes, com correntes e radiações que se cruzaram um dia num cérebro mais ou menos excepcional" (Tarde, 1978, p. 13-14).

Este tipo de invenção não seria, por si só, um facto "puramente" social. Para sê-lo, não basta copiar a estrutura de um meme digital e adaptá-lo a outra dimensão ou dinâmica. Em seu entender, a "personalidade original" do sujeito ou da invenção não é encontrada quando ele imita um outro ou alguns outros, poucos,

mas quando, em vez de se regular sobre algum ou sobre alguns, se recebe de cem, de mil, de dez mil pessoas consideradas cada uma sob um aspecto particular, elementos de ideia ou de ação que se combinam em seguida, a própria natureza e a escolha destas cópias elementares, assim como a sua combinação, exprimem e acentuam a nossa personalidade original. (Tarde, 1978, p. 15)

Embora existam, em Tarde, algumas reminiscências de uma filosofia essencialista, em que perto de um platonismo é sugerida a ideia que passa a cópia, eis que ele se revela mais aristotélico e hilemórfico, consagrando à subjetividade e à individuação o lugar onde se extrai esse "original". A ideia de Tarde é que o sujeito ou a invenção devem ter, em vários aspetos particulares, várias opções de escolha para se "fazerem originais". Este é, em seu entender, um dos grandes benefícios da imitação. Essa "personalidade 
original", do sujeito ou da invenção, desabrocha ao mesmo tempo que se afirmam processos de individuação e sociabilidades (sobretudo as mais consumadas).

Todas estas considerações, até agora contidas ainda no prefácio da segunda edição, surgem de uma outra premissa que consta no prefácio da primeira edição: a de que "o real não é explicável senão ligado à imensidade do possível, isto é, do necessário sob condição, em que ele navega como a estrela no espaço infinito. O realizado parece não ser mais do que um fragmento do realizável)" (Tarde, 1978, p. 18). Este "real" é, para Tarde, entendido como o fruto, em primeiro lugar, de uma "repetição universal" (Capítulo I). Ora, neste real enquanto mero fragmento do realizável, entende que uma invenção mais não é do que "uma inovação qualquer ou um aperfeiçoamento, por mais ténue que pareça, acrescentado a uma inovação anterior, em qualquer ordem de fenómenos sociais (linguagem, religião, política, direito, indústria, arte)" (Tarde, 1978, p. 22). Reduz, assim, a "originalidade" da invenção a um encadeamento social, conectado pelas dinâmicas inerentes à imitação. Esses encadeamentos geram "mutações graduais" que "parecem dar continuação, sem descontinuidade visível, às mutações anteriores na corrente das quais elas se inserem" (Tarde, 1978, p. 22). O que, no seu entender, o leva a considerar que "socialmente, não passa tudo de invenções e imitações, e estas são os rios de que aquelas são as montanhas" (Tarde, 1978, p. 23). O princípio social é este: "a iniciativa individual [invenção] seguida da imitação" (Tarde, 1978, p. 23).

A iniciativa individual, seguida da imitação social, gera a ciência. Quer dizer, para Tarde, só existe ciência porque existem semelhanças e repetições. E para isso terão que existir associações e adesões, identificações ou contra-identificações - perspetiva muito presente em Maffesoli (2014). Nunca processos estáveis, como por vezes se pode pressupor com a "identidade". Tais semelhanças e repetições permitem prever, numerar e medir. A ciência "vive de número e medida" (Tarde, 1978, p. 25). No entanto, uma ciência nova, como era o caso da sociologia nos seus primórdios, deveria comparar, entre si, as semelhanças e as repetições, bem como "observar o laço de soli- dariedade que une as suas variações concomitantes" (Tarde, 1978, p. 26). Era esta a grande proposta que Tarde apresentava para que a sociologia se tornasse ciência. A epistemologia era a de que "quando as coisas que se repetem permanecem unidas umas às outras ao multiplicarem-se, a repetição, então chama-se crescimento e não simplesmente série" (Tarde, 1978 , p. 26). Partia do pressuposto de que "as repetições existem pelas variações. As repetições só têm uma razão de existir, a de mostrar sob todas as suas faces uma originalidade única que procura tornar-se clara" (Tarde, 1978, p. 27).

Voltemos ao relacionamento entre a teoria de Tarde e o mundo atual: pensemos na repetição de expressões de ódio no Facebook enquanto demonstração "sob todas as suas faces" de um crescimento que revela uma postura que se torna clara para demonstrar uma insatisfação social diante de um determinado objeto de ódio (Costa, 2020a). Glosando Tarde (1978, p. 28), os discursos de ódio no Facebook contra um qualquer objeto (futebol, política, corrupção, etc.) são uma repetição que parte de uma variação/ inovação possibilitada pelos modos de comunicação digital. Este "normal atual" deriva desse acidental. Isto é,

uma invenção humana, pela qual um novo género de imitação é inaugurado (uma nova série aberta, por exemplo, a invenção da pólvora de canhão, ou dos moinhos de vento, ou do telégrafo de Morse), está para a ciência social como a formulação duma nova espécie vegetal ou mineral está para a biologia. (Tarde, 1978, p. 32)

Neste sentido, a ciência social "existe, em estado disperso, na pequena experiência de cada um e que basta reunir-lhe os fragmentos" (Tarde, 1978, p. 32). Estudar as redes digitais e as suas idiossincrasias é, portanto, reunir fragmentos do social, que podem depois ser segmentados por alinhamentos descritivos.

Esta epistemologia tardeana desemboca numa outra proposição: "todas as semelhanças de origem social que se observam no mundo social são o fruto directo ou indireto da imitação sob todas as suas formas: imitação-costume ou imitação-moda, imitação-simpatia ou imitação-obediência, imitação-ins- 
trução ou imitação-educação, imitação-espontânea ou imitação-reflectida, etc." (Tarde, 1978, p. 35). Estas semelhanças resultam não de dinâmicas recentes, mas "de irradiações imitativas emanadas de invenções antigas, ao mesmo tempo mais estendidas e mais intensas porque tiveram o tempo necessário para se desdobrarem e se estabelecerem em hábitos, em costumes, em 'instintos de raças' ditos fisiológicos" (Tarde, 1978, p. 40). O que é dinâmico, na medida em que "as imitações (palavras de uma língua, mitos de uma religião, segredos de uma arte militar, formas literárias, etc.) modificam-se ao passarem de uma raça ou de uma nação para outra" (Tarde, 1978, p. 43). Usa, como exemplo desta explanação, a questão linguística: "ao passar do meio romano para o meio espanhol ou gaulês, as palavras latinas diversas foram transformadas de uma maneira idêntica e característica, tornando-se cada letra uma ou outra letra determinada" (Tarde, 1978, p. 43). Eis o seu hilemorfismo.

Por seu turno, considera que as colisões entre imitações dependem, portanto, do sentido das repetições ou do modo como essas podem ou não interagir entre sequências. Se duas imitações da mesma ordem, mas diferentes em forma ou conteúdo, se encontram com um mesmo sujeito, ou se complementam, se confirmam, se unificam ou se fortalecem, significa que tal tende a entrar em contágio imitativo. Se, pelo contrário,

se estorvam ou se contradizem numa alma ou nas almas de um povo, há estagnação moral dessa alma, desse povo, na indecisão e na dúvida, até que, por um esforço brusco ou lento, essa alma ou esse povo se separa em dois e sacrifica a sua crença ou a sua paixão menos querida. (Tarde, 1978, pp. 45-46)

Para Tarde, existem três tipos de interferências dinâmicas impostas pela imitação: i) que quando uma conjetura que olhava como "bastante provável vem a coexistir em mim, no mesmo estado de espírito, com a leitura ou a reminiscência de um facto que eu tenho por quase certo, se eu me aperceber de repente que este facto confirma essa conjectura" (Tarde, 1978, p. 47). Aí, o facto parece-me certo e eu sigo-o; ii) que "encarado historicamente, o mesmo facto", (paixão nobre, a paixão vil, a crença no destino, etc.) se propaga num contágio imitativo nas diferentes contingências. Quer dizer, a sociedade passa a existir "desde o dia em que um homem qualquer copiou um outro" (Tarde, 1978, p. 49); iii) que "nenhuma interferência mental iguala a de um desejo e de uma crença". O exemplo que Tarde convoca é: "queria muito ser orador no parlamento, e um cumprimento de amigo me persuade de que eu acabo de revelar de repente um verdadeiro talento oratório; esta persuasão aumenta a minha ambição, que contribui, de resto, para me deixar persuadir". Já pelo contrário, uma crença "aviva um desejo, tanto porque ela faz julgar mais realizável o objeto deste, como porque ela é a aprovação dele" (Tarde, 1978, p. 50). Estas interferências podem ser do tipo de combinações, como no caso do desejo e da crença, ou do tipo de interferência-luta, como duas aptidões incompatíveis, mas que entram em tensão (desejo e privação desse mesmo por ordem legal, por exemplo).

Além destas interferências dinâmicas, Tarde enuncia três formas de repetição: geração, ondulação e imitação. Sobre as suas diferenças, o autor considera que "a solidariedade destas três formas é unilateral, não recíproca". (Tarde, 1978, p. 55). A imitação depende da ondulação e a ondulação depende da geração. $\mathrm{E}$ tal não acontece ao contrário. Em última instância, "a imitação é uma geração à distância" (Tarde, 1978, p. 55).

Não obstante, essas "três formas de repetição são três repetições do mesmo esforço" (Tarde, 1978, p. 56). Por exemplo: "a obra imitada é-o de ordinário no seu estado de desenvolvimento completo, sem passar pelas tentativas do primeiro obreiro. Este processo é artístico e, portanto, superior em celeridade ao processo vital: suprime as fases embrionárias, a infância e a adolescência" (Tarde, 1978, p. 56). A imitação tem, assim, um sentido socialmente acelerador, ao passo que a geração ou a ondulação se mantém com os ritmos iniciais da sua própria função. Ao acelerar processos, a imitação gera maior número de imponderáveis. Tarde convoca o exemplo daquilo que é socialmente inverosímil: "o erro, em política, está em não acreditar no inverosímil e em nunca prever o que nunca se viu" (Tarde, 1978, p. 58).

No capítulo II, Tarde começa por sintetizar uma das principais teses deste livro: "toda a semelhança so- 
cial tem a imitação por causa" (Tarde, 1978, p. 59). É aqui que o autor expande a sua sociologia, conectando-a à psicologia, à biologia, à história ou à química. Considera que as semelhanças, embora sociais, têm por causa

repetições de ordem biológica e de ordem física, transmissões hereditárias de funções e de órgãos que constituem as raças humanas, e transmissões vibratórias de temperaturas, de cores, de sons, de eletricidade, de afinidades químicas, que constituem os climas habitados e os solos cultivados pelo homem. (Tarde, 1978, p. 62)

Em seu entender, o sociólogo tem o "direito de tratar as analogias funcionais das diversas línguas, das diversas religiões, dos diversos governos, das diversas civilizações, com um desprezo igual, e as suas homologias anatómicas com um respeito igual" (Tarde, 1978, p. 62). Por exemplo: Teotl (azteca) e Théos (grego) têm o mesmo significado: Deus. A este respeito, Tarde sugere "uma relação fatícia entre duas abstrações" (Tarde, 1978, p. 63), que não significa necessariamente um elo entre dois seres mas que não pode ser desconsiderado. A mesma necessidade humana gera uma ideia semelhante. Ou seja, semeIhanças de ordem biológica e não social geram resultados sociais semelhantes. Tarde considera que são essas "necessidades virtuais e profundas" que levam o antropoide a imaginar uma religião ou uma linguagem, permitindo-lhe realizar possíveis até então irrealizados. Foi depois a propagação por imitação a verdadeira causa da sua disseminação (Tarde, 1978, p. 65). De facto, "o acto original de imaginação teve por efeitos não só os actos de imitação diretamente emanados dele, mas também todos os actos de imaginação que ele sugeriu e que eles próprios sugeriram de novo, e assim sucessivamente" (Tarde, 1978, pp. 65-66).

Voltemos à questão dos discursos de ódio nas plataformas digitais: no sentido tardeano, o facto de o humano ser violento discursivamente quando algo Ihe provoca ira, tal significa uma repetição da sua hereditariedade, e a imitação desse ódio nas redes digitais reflete somente uma semelhança social proporcionada pelas possibilidades que a atualidade concede (Tarde, 1978, p. 66). Ou pensemos num outro caso: um anúncio publicitário inspirado num meme de sucesso que circula nas redes digitais. De que tipo de semelhança estamos a falar em sentido tardeano? De uma invenção que emanou de um meme, mas que resultou, acima de tudo, de um:

cruzamento feliz, num cérebro inteligente, de uma corrente de imitação, seja com outra corrente de imitação que o reforça, seja com uma perceção exterior intensa, que faz aparecer com um aspeto imprevisto uma ideia recebida, ou com o sentimento vivo de uma necessidade da natureza que encontra num procedimento usual expedientes inesperados. (Tarde, 1978, p. 66)

Ou seja, Tarde considera que a semelhança ou a invenção "que surge é um possível realizado entre mil, entre os possíveis diferentes", isto é, "entre os necessários condicionais, que a invenção-mãe donde ela deriva trazia no seu ventre; e ao aparecer ela torna impossíveis doravante a maior parte desses possíveis, torna possíveis uma multidão de outras invenções que antes não o eram". De facto, "estas existirão ou não existirão, segundo a direção e a extensão do raio da sua imitação através das populações já esclarecidas com tais ou tais outras luzes". Pois é verdade que entre "as que existirão, só as mais úteis, se se quiser, sobreviverão, mas entenda-se por isso as que responderão melhor aos problemas do tempo; porque qualquer invenção, como qualquer descoberta, é uma resposta a um problema" (Tarde, 1978, p. 68).

Por outras palavras, Tarde sugere que esse "contágio irradiador das civilizações" não está apenas no contacto direto entre civilizações de um determinado ponto de vista (comercial, bélico, estético, etc.), mas antes nos diferentes modos de contacto diretos e indiretos - muitas vezes subtis e até inconscientes (Tarde, 1978, p. 72). Nesse diferendo, como os modos de contacto entre civilizações ou comunidades geram uma diversidade mais alargada, Tarde entende que "o costume, isto é, a imitação exclusiva deve prevalecer sobre a moda, sobre a imitação sectária" (Tarde, 1978, p. 75).

No capítulo III, o autor persegue as suas inquietações ao esboçar uma resposta à questão "Que é uma sociedade?" (Tarde, 1978, p. 83). Para isso, reflete primeiro sobre o ideal social de futuro, questionando:

o ideal social de futuro não é a reprodução em grande da cidade antiga, em que os escravos, como se disse e repetiu à saciedade, seriam substituídos por má- 
quinas, e onde o pequeno grupo de cidadãos iguais, semelhantes, não cessando de se imitar e de se assimilar, independentes, aliás, e inúteis uns aos outros, pelo menos em tempo de paz, tornar-se-ia a totalidade dos homens civilizados? (Tarde, 1978, p. 88)

O que Tarde pretende com esta reflexão sobre o futuro é mencionar a importância dos laços estabelecidos entre passado e presente que reproduzem semelhanças e repetições, na medida em que "o laço social vai-se estreitando à medida que outros traços comuns se juntam a esse, todos de origem imitativa" (Tarde, 1978, pp. 92-93). Com isto acaba por alcançar a sua definição de grupo social: "uma coleção de seres enquanto está em vias de se imitar entre si, ou enquanto, sem se imitarem atualmente, se assemeIham e os seus traços comuns são cópias antigas de um mesmo modelo" (Tarde, 1978, p. 93).

Esta definição de grupo social é o reflexo de uma leitura "associativista", onde antes das relações, da comunicação e das identificações sociais estão as associações, muitas delas já sugeridas nas invenções ou ideias, enquanto bases das sociedades. Uma "sociedade é sempre, em diversos graus, uma associação, e uma associação é para a socialidade, para a imitatividade, por assim dizer, o que a organização é a para a vitalidade ou mesmo o que a constituição molecular é para a elasticidade do éter" (Tarde, 1978, pp. 9596). Está aqui um dos primeiros gatilhos para uma sociologia das associações, posteriormente trabalhada por Latour (2009; 2012).

E se um grupo social é, em seu entender, essa coleção de seres em imitação ou em vias de imitação, uma nação é "um acordo de tradições, de costumes, de educações, de tendências, de ideias que se propagam imitativamente por vias diferentes, mas subordinando-se hierarquicamente e ajudando-se fraternalmente" (Tarde, 1978, p. 96). Tarde nunca se afasta dos seus conceitos.

Com isto, Tarde entende que aquilo que se torna homogéneo resulta da diversidade, isto é, das semeIhanças que se extraem da diversidade. A alteridade, dos sujeitos ou dos grupos, resulta das semelhanças que a diversidade regurgita. Há aqui uma leitura que corta radicalmente com noções deterministas, onde o heterogéneo, e não o homogéneo, é o grande res- ponsável pela semelhança que se vai reproduzindo ou revelando. Sem um heterogéneo inicial, o homogéneo que o recobre e o dissimula jamais teria existido ou poderia existir (Tarde, 1978, p.96). É assim, escreve, que "o passado responde pelo futuro" (Tarde, 1978, p. 98).

as comunidades homogéneas e igualitárias, dizemos nós, precedem as Igrejas e os Estados pela mesma razão pela qual os tecidos precedem os órgãos; e, por outro lado, a razão pela qual os tecidos e as comunidades uma vez formadas se organizam, se hierarquizam, não é senão a causa mesma da sua formação. $\mathrm{O}$ crescimento do tecido ainda não diferenciado nem utilizado atesta a ambição, a avidez especial do germe que se propagou; como a criação de um clube, de um círculo, de uma confraria de iguais, atesta a ambição do espírito empreendedor que the deu nascimento propagando ao acaso a sua ideia pessoal, o seu plano pessoal. Ora, é para se espalhar ainda mais e se defender contra os inimigos aparecidos ou previstos que a comunidade se consolida em corporação hierarquizada, que o tecido se faz órgão. Agir e funcionar, para o ser vivo ou social, é uma condição sine qua non de conservação e de extensão da ideia mestra que ele traz em si mesmo e à qual de início bastou multiplicar-se em exemplares uniformes para se desenvolver algum tempo. Mas o que quer a coisa social antes de mais, como a coisa vital, é propagar-se e não organizar-se. A organização não é mais do que um meio de que a propagação, de que a repetição generativa ou imitativa, é o fim" (Tarde, 1978, pp. 98-98).

Assim, Tarde afina os seus conceitos e respostas: "que é a sociedade? Nós respondemos: é a imitação" (Tarde, 1978, p. 99). Aos críticos que invocavam o psicologismo de Tarde na sua teoria social, existem passagens claras sobre o seu posicionamento. É o caso da distinção entre o conceito de memória e de hábito: "a memória é um hábito puramente nervoso; o hábito, uma memória ao mesmo tempo nervosa e muscular. Assim, qualquer ato de perceção, enquanto implica um acto e memória, supõe uma espécie de hábito, uma imitação inconsciente de si mesmo por si mesmo. Esta não tem nada de social" (Tarde, 1978, p. 100). Esta nuance coloca-o a dar primazia, de um ponto de vista social, à ideia tornada ação, que é outra coisa não psicológica, quer dizer, a ideia enquanto coisa social, que se realiza através da imitação e da repetição. Aí já temos um facto social. A ideia é 
processo em imitação e não um acontecimento, logo portanto é um facto social ao contrário de uma memória ou um hábito que acontece a partir de dentro.

a ação não é senão a continuação de uma ideia, uma aquisição de fé estável. Mas se a ideia ou a imagem rememorada foi posta inicialmente no espírito por uma conversa ou por uma leitura, se o acto habitual teve por origem a vista ou o conhecimento de uma ação análoga de outrem, esta memória e este hábito são factos sociais ao mesmo tempo que psicológicos (Tarde, 1978, p.100).

Regressemos ao digital: o que é um vídeo ou um meme em propagação viral no digital? Não é algo visto e partilhado por outrem, que age ou sugere, através do conteúdo e da sua repetição ou imitação, constituindo-se num facto social? Seria deste modo que Tarde entenderia hoje o mundo. Um mundo de imitações em ambiente digital, e essas imitações enquanto factos sociais por se tratarem de "uma memória e um hábito, não individuais mas coletivos". Do mesmo modo "que um homem não olha, não escuta, não caminha, não se levanta, não escreve, não toca na flauta, e, o que é mais, não inventa e não imagina, a não ser em virtude de recomendações musculares múltiplas e coordenadas" (Tarde, 1978, pp. 100-101).

Como tal, a sua proposta de método científico é a de "esclarecer o complexo pelo simples, a combinação pelo elemento, e explicar o laço social entrelaçado e complicado, tal como nós o conhecemos, pelo laço social ao mesmo tempo muito puro e reduzido à sua mais simples expressão" (Tarde, 1978, pp. 101102).

Depois disto, Tarde convoca algumas figuras. Primeiro, o hipnotizador. O social, que leva por adiante a nação e os grupos sociais, é entendido como um grande hipnotizador. Esse hipnotizador "não tem necessidade de mentir para ser acreditado cegamente pelo hipnotizado, não tem necessidade de aterrorizar para ser obedecido passivamente. Ele é prestigiado, isso diz tudo" (Tarde, 1978, p. 103). Por seu turno, o sujeito hipnotizado contém

uma certa força potencial de crença e de desejo imobilizado em recordações de toda a espécie, adormecidos mas não mortos, que esta força as- pira a atualizar-se como a água do pântano a escoar-se, e que, sozinho, na sequência de circunstâncias singulares, o hipnotizador está à altura de Ihe abrir a saída necessária. (Tarde, 1978, p. 103)

Como exemplo, Tarde recorda outras civilizações:

é preciso pensar em qualquer povo antigo de uma civilização muito diferente da nossa, Egípcios, Espartanos, Hebreus... Será que essas pessoas não se julgavam autónomas como nós, embora sendo sem o saber autómatos de que os seus antepassados, os seus chefes políticos, os seus profetas premiam o botão, quando elas não o premiam umas às outras? (Tarde, 1978, p. 102)

Mais do que um devir, Tarde descreve, nos sujeitos e grupos, uma submissão a um "estado social", quer dizer, um "estado hipnótico, [que] não passa de uma forma de sonho, um sonho de comando e um sonho em ação. Não ter senão ideias sugeridas e julgá-las espontâneas: tal é a ilusão própria do sonâmbulo, e também do homem social" (Tarde, 1978, p. 102). Esse estado social hipnotizador "não tem necessidade de falar para ser acreditado e para ser obedecido; basta-Ihe agir, fazer um gesto por mais imperceptível que seja. Este movimento com o pensamento e o sentimento de que ele é o sinal, é imediatamente reproduzido" (Tarde, 1978, p. 104). Não estaria aqui Tarde a sugerir que "o meio é a mensagem", como o fez mais tarde Mcluhan (2007)? Que o emissor e a sua legitimidade já são, por si só, a grande força?

Contudo, o lado sonâmbulo dos sujeitos e o estado social hipnotizador são somente algumas consequências da vida social. Há também o lado desperto. E é na vida "desperta, e entre pessoas que parecem não exercer nenhuma ação magnética uma sobre a outra que se produz esta mútua imitação, este mútuo prestígio" (Tarde, 1978, p. 104). É o caso da simpatia, origem primeira da "sociabilidade e a alma visível ou escondida de todas as espécies de imitação, mesmo da imitação invejosa e calculada, mesmo da imitação de um inimigo. Está claro que a própria simpatia começa por ser unilateral antes de ser mútua" (Tarde, 1978 , p. 104).

Este lado escondido ou dissimulado da imitação, que pode estar na simpatia, mas também noutras dinâmicas da sociabilidade, gera ações, sendo que 
uma "ação qualquer de qualquer um de entre nós dá aos seus semelhantes que são disso testemunhas a ideia mais ou menos irrefletida de a imitar" (Tarde, 1978, p. 104). Há em Tarde uma forte preocupação com o irrefletido e o inconsciente no processo imitativo - antecipando as teses de Jung (1979). E mesmo até quando descreve uma resistência inconsciente à sugestão irrefletida de imitar, "é porque ela é então neutralizada neles por sugestões antagónicas, nascidas de recordações presentes ou de perceções exteriores" (Tarde, 1978, p. 104).

Depois das figuras de hipnotizador, de sonâmbulo e de desperto irrefletido, Tarde convoca, simultaneamente, os conceitos de inventor social e de iniciador social. O inventor é aquele que cria a ideia e o iniciador aquele que a traz para a ação, permitindo posteriormente a sua propagação através da imitação. Um exemplo de um inventor é um teórico político. Um exemplo de um iniciador é um líder que tenta aplicar essa teoria política. O primeiro cria a ideia e o segundo coloca-a em prática. Por seu turno, os seguidores do líder vão propagar a concretização prática proposta pelo líder e inspirada no teórico (Tarde, 1978, pp. 106-17). Retomando o exemplo dos tempos atuais, onde muitos dos líderes são agora influencers digitais em plataformas como o YouTube, esta reflexão revela-se ainda mais certeira. Nesses contextos, os influencers digitais são iniciadores de tendências e os seus milhares de consumidores são seguidores desse movimento iniciado, deambulando, com tendências, opiniões ou ideias, do digital para o offline e vice-versa (Costa, 2020b).

Há, no entanto, alguns reparos sobre a dinâmica em torno dos seguidores, tanto em intensidade como em autonomia. Sobre a intensidade, Tarde considera que "quanto mais as sugestões do exemplo se multiplicam e se diversificam em torno do indivíduo, mais a intensidade de cada uma delas é fraca (Tarde, 1978 , p. 109). Sobre a autonomia, derivado dessa intensidade mais fraca devido a um grande número de sugestões, mais o sujeito "se determina na escolha a fazer entre elas, pelas preferências tiradas do seu próprio carácter, por um lado, e, por outro, em virtude das leis lógicas" e extra-lógicas da imitação (Tarde, 1978, p. 109).
No seu entender, os inventores, por mais que sejam numerosos, são fundamentais para iniciadores e seguidores, pois

pensar espontaneamente é sempre mais fatigante do
que pensar por outro. Assim, todas as vezes que um
homem vive num meio animado, numa sociedade in-
tensa e variada, que lhe fornece espetáculos e concer-
tos, conversas e leituras sempre renovadas, ele dis-
pensa-se gradualmente de todo o esforço intelectual;
e entorpecendo-se ao mesmo tempo e superexcitan-
do-se cada vez mais, o seu espírito, repito-o, faz-se so-
nâmbulo. Eis aqui o estado mental próprio de muitos
citadinos. Ora, a vida urbana não é a vida social con-
centrada e levada ao extremo? (Tarde, 1978, p. 110)

Por seu turno, o iniciador (líder) contém um papel importante na dinâmica social, na medida em que é alguém que alcança um certo prestígio. Ora, "um homem prestigiado dá um impulso, em breve seguido por milhares de pessoas que o copiam em tudo e para tudo, e dele retiram mesmo o seu prestígio, em virtude do qual elas agem sobre milhões de homens inferiores" (Tarde, 1978, p. 110).

Mas é o líder, por si só, que gera o sonambulismo social? é o medo, a agressividade ou a direção que representa ou provoca? Ou é a genialidade da ideia, criada pelo inventor, que o líder perpassa? Nem uma coisa nem outra. Para Tarde, o sonambulismo social visível nos seguidores tem como grande motor a admiração, esse "clarão da superioridade sentida e penosa" (Tarde, 1978, p. 111). Encantado ou intimidado, qualquer um pode admirar e sentir essa ideia de superioridade, pois em admiração eis que germina um "estado social nascente". É a partir da admiração, sobre uma pessoa que motiva para ou uma ideia que conduz a, que nasce "um estado social nascente, que se produz todas as vezes que se passa de uma sociedade para outra, ou que se entra na vida social exterior ao sair da família" (Tarde, 1978, p. 112).

E se o sonambulismo social tem como motor a admiração, esse maior ou menor caracter sonâmbulo depende das predisposições individuais para a sociabilidade. Tarde considera que o sociável é mais imitador do que o tímido, e que tende a fazer mais vezes a imitação de modas. Pelo contrário, o tímido, tal como a intimidação em geral, "desempenha so- 
cialmente, com o consentimento de todos, um papel imenso, mal compreendido algumas vezes" (Tarde, 1978, p. 112).

Mas não é só a timidez que desempenha um papel social considerável. Também o respeito, essa "impressão exemplar de uma pessoa sobre a outra, psicologicamente polarizada" (Tarde, 1978, p. 112), é uma das forças motriz para a imitação, e vice-versa. Para o sociólogo, "aqueles que imitamos são por nós respeitados" (Tarde, 1978, p. 112) e "aqueles que respeitamos são por nós imitados ou tendemos a imitá-los" (Tarde, 1978, pp. 112-113).

Todas estas figuras dinâmicas colocam Gabriel Tarde, já na parte final do livro, a tornar pressupostos em leis, leis da imitação. Primeiro, começa por dividir essas leis em dois tipos: leis lógicas e leis extra-lógicas (ou não-lógicas).

Depois de todo o edifício teórico considerado, entende que as leis lógicas da imitação atuam quando uma inovação é considerada por um homem (num exercício de subjetividade) mais útil ou verdadeira do que outras. Estas são lógicas por três ordens de razão: i) "a origem de uma invenção envolve a recombinação de imitações existentes, e esta origem será influenciada pelo contexto social e pelas capacidades de todos os envolvidos na recombinação" (Tarde, 1978 , p. 169). Tarde dá como exemplo a linguística. Por um lado, pequenas invenções linguísticas foram sugeridas aos primeiros linguistas "por imitação de si ou de outrem", isto é, por contágio social imitativo (Tarde, 1978, p. 169). Por outro lado, linguistas de renome criaram logicamente, em imitação ao latim, palavras que associaram ao prestígio da sua pessoa conseguindo transpô-las para circulação (Tarde, 1978, p. 171); ii) a segunda lei lógica menciona a dinâmica da sua eficácia: o sucesso de uma imitação em espalhar-se geometricamente a partir do seu ponto de origem será uma função do seu grau de adaptação, isto é, a compatibilidade com o ambiente de imitações existentes. Neste sentido, em Tarde tudo aquilo que é imitado é sempre uma crença (ideia ou querer) e/ ou um desejo (opinião ou desígnio) que se manifesta no espírito de uma língua, nas orações de uma religião, nos artigos de um código, nos deveres morais, no trabalho da indústria ou nos processos da arte; iii) a terceira e última lei lógica versa sobre a seleção das imitações, isto é, "a adoção de uma imitação ocorre ou através de uma 'substituição' envolvendo um 'duelo lógico' e 'luta' entre duas alternativas ou através de 'acumulação', um processo ligado a uma união lógica de imitações". No seu entender, a adoção de uma imitação é possível porque existe progresso, ainda que seja apenas com a invenção que se geram nuances evolutivas. $O$ progresso em Tarde é então "uma espécie de meditação colectiva e sem cérebro próprio, mas tornado possível pela solidariedade (graças à imitação) dos múltiplos cérebros de inventores, de sábios que permutam as suas descobertas sucessivas" (Tarde, 1978, p. 176).

Quanto às leis extra-lógicas da imitação, Tarde também as divide em três dinâmicas: no movimento do interior para o exterior; no movimento do superior para o inferior; e na alteração dos costumes e das modas. Com a primeira lei extra-lógica dá-se um deslocamento da disposição do espírito para o comportamento que esse induz. Aqui entram em cena forças subjetivas e idiossincráticas. Já com a segunda lei-lógica, surge esse movimento entre cima e baixo com dinâmicas de imitação em ambos os sentidos ainda que a ação sugestiva e contagiosa da elite seja mais poderosa. O que, em certo sentido, também se relaciona com terceira lei extra-lógica, em que a imitação produz a alteração de costumes e modas. Em todo o caso, Tarde refere que

mesmo no caso em que a acção das leis lógicas não intervém, não é somente o superior que se faz imitar pelo inferior, o patrício pelo plebeu, o nobre pelo vilão, o clérigo pelo leigo, mais tarde o parisiense pelo provinciano, o homem das cidades pelo camponês, etc.: é ainda o inferior que, numa certa medida, bem menor, é verdade, é copiado ou tende a ser copiado pelo superior. Quando dois homens estão em presença e em contacto prolongado, por mais alto que seja um e por mais baixo que seja o outro, eles acabam sempre por se imitar reciprocamente, mas um muito mais e o outro muito menos. (Tarde, 1978, p. 247)

A receção à teoria social de Tarde tem sido "proporcionalmente mais negativa quanto mais se caminha na direção do pólo científico e, em oposição, mais positiva quanto mais se aproxima do campo literário" (Consolim, 2008, p. 275). Considerado um 
"filósofo", "dedutivo", "engenhoso", "original”, "poeta" e "metafísico" pelos mais literários, e um "generalista", "ambíguo", "não empirista" e "simplista" pelos mais científicos, criou uma dualidade na receção que o considerou defensor dos pensadores "livres" e da literatura/moral e opositor dos universitários e da ciência (Consolim, 2008).

Não obstante, em nosso entender As Leis da imitação transcendem esta dualidade na receção e ajustam-se, na perfeição, às dinâmicas sociais e relacionais que hoje, sobretudo em ambientes digitais (mas não só), são passíveis de ser constatadas. Surgem-nos apenas duas considerações: primeiro, descreve muitas vezes a imitação quando por vezes quer sugerir transmissão, ainda que a largueza do conceito de imitação permita a flexibilidade e a simplicidade necessária para uma forte compreensão das ideias. Depois, não relaciona, diretamente, as leis da imitação com o poder ou a dominação, sendo que as leis extra-lógicas, nos seus movimentos entre superior e inferior, ou entre costumes e modas, parecem estar, como demonstrou Simmel (2008) em A Filosofia da Moda, intimamente ligadas às forças que emanam de lógicas sociais de poder e de dominação.

Ficam por responder, em nosso entender, algumas questões: não será o poder capaz de gerar novas imitações? De limitar umas e permitir outras? Não estará o poder, ao limitar e impedir por exemplo os vários tipos de crime, a abrir a porta a outras sugestões, que depois entram na corrente imitativa? Não será o poder um facto social imitativo, em que tanto o inventor da lógica que lhe dá substrato como o iniciador que o propaga contribuem para a produção de semelhanças e repetições tendo por base a lógica de poder e dominação inscrita no inventor e na sua criação? O tal exemplo do digital, onde imperam dinâmicas de poder impostas por inventores de plataformas (Facebook, YouTube, Google, etc.) e de captologias (Costa, 2020c), aproveitadas e capitalizadas por iniciadores que geram movimentos de reforço do poder tecno-digital de cima para baixo, é disso um bom exemplo. Mas também aqui Gabriel Tarde é profícuo: num texto com 131 anos, coloca-nos a repensar toda a estrutura da imitação e do poder na era atual. Um verdadeiro clássico da teoria social.

\section{Referências:}

Consolim, M. C. (2008). Gabriel Tarde e as ciências sociais francesas: afinidades eletivas. Mana 14 (2): 269-298. DOI: 10.1590/S0104-93132008000200001

Costa, P. R. (2020a). Uma cartografia do ódio no Facebook: gatilhos, insultos e imitações. Comunicação Pública, 15(29): 01-28. Retirado de https://journals.openedition.org/ $\mathrm{cp} / 11367$

Costa, P. R. (2020b). A presença de arquétipos nos youtubers: modos e estratégias de influência. Revista Galáxia, 45: 5-19. http://dx.doi.org/10.1590/1982-25532020347613

Costa, P. R. (2020). Impactos da captologia. Problemáticas, desafios e algumas consequências do "dar vistas" ao ecrã em rede. Sociologia Online, 23: 74-94. DOI: https://10.30553/ sociologiaonline.2020.23.4

Deleuze, G. \& Guattari, F. (2004). O Anti-Édipo-Capitalismo e Esquizofrenia. Lisboa: Assírio \& Alvim.

Deleuze, G. (2006). Diferença e Repetição. Lisboa: Relógio D’água.

Jung. C. G. (1979). O eu e o inconsciente. Petrópolis: Editora Vozes.

Latour, B. (2009). Jamais fomos modernos: ensaio de antropologia simétrica. Rio de Janeiro: Editora 34.

Latour, B. (2012). Reagregando o social: uma introdução à Teoria do Ator-Rede. Salvador: Edufba.

Maffesoli, M. (2014). O Tempo Das Tribos - O Declínio do Individualismo Nas Sociedades de Massa. Rio de Janeiro: Forense Universitária.

Mcluhan, M. (2007). Os Meios de Comunicação como Extensões do Homem. São Paulo. Cultrix.

Simmel, G. (2008). A filosofia da moda e outros escritos. Lisboa: Edições Texto \& Grafia. 